\title{
RISK AS A MENTAL ELEMENT OF CIVIL LIABILITY OF POLICE OFFICERS IN UKRAINE
}

\section{Olha Panchenko}

\section{INTRODUCTION}

Risk is one of the least studied concepts in legal science. For example, in criminal law, risk is investigated within the institution of circumstances that exclude criminality of an act (Section VIII of the Criminal Code of Ukraine) ${ }^{1}$. Thus, the actions of a person, who caused harm to legitimate interests in the conditions of a justified risk in order to achieve socially useful purpose, are recognized as lawful, and the person who caused harm under such conditions is not held criminally liable.

The problem for jurisprudence lies not in the mere fact of the existence of risky situations, but in the determination of criteria for the distinction between lawful and unlawful risk. In the theory of criminal law, within which the issue of risk was given special consideration, the following types of justifiable risk are defined: industrial, economic, professional, medical or technical, medical, pedagogical, sports, creative, administrative, risk in law enforcement, scientific experiment, etc. It appears from the foregoing that the problem of the risk cannot be solved within the criminal or any other area of law. It is complex, intersectoral problem.

The scientists summarize the factors that have actualized the problem of risk in Ukraine: 1) the rapid development of social and political relations in Ukraine encouraged the emergence of new relations in society; 2) the development of international relations at all levels is characterized by instability and danger both for the sovereignty of the State directly and for the world as a whole; 3 ) the role of Ukraine in certain international processes is of an exceptional nature, arising from its geographical position, natural, human, economic potential, etc. It is obvious that risk covers all aspects of human life. This category is related to production, creativity, recreation, sports, scientific and technological progress, etc. Risk is an integral part of many professional activities, particularly of law enforcement activities. Initiative, innovations are not possible without risk. The term "initiative" has two meanings: 1) the first step in any case, an act; 2) the ability to come up with new ideas, suggestions; ability to start any business independently; persistence, energy,

${ }^{1}$ Kryminaljnyj kodeks Ukrajiny. Stanom na 18 zhovtnja 2019 r. [Criminal Code of Ukraine: as of October 18, 2019]. Kyiv: Alerta. (in Ukrainian). 
entrepreneurship. Therefore, it is natural that the concept of risk is actively used in various fields of knowledge - not only in law, but also in economics, management, medicine, sports, and psychology ${ }^{2}$.

Risk is a multidimensional category, which is reflected in many rules of civil law, but it is revealed variously, using different terminology. For example, the Civil Code of Ukraine ${ }^{3}$ refers to the risk of accidental destruction and accidental damage to property (Art. 323 of the Civil Code of Ukraine), the risk of accidental destruction or accidental damage to the collateral (Article 580 of the Civil Code of Ukraine), the risk of accidental destruction or accidental damage to an item (Article 594 of the Civil Code of Ukraine), the risk of accidental destruction or accidental damage to the goods (Article 668 of the Civil Code of Ukraine), etc. Articles 924 and 947 of the Civil Code of Ukraine provide a somewhat opposite wording of the category under consideration - mainly the risk of "loss, deficiency, spoilage or damage". And this, obviously, does not limit the use of the term in civil law.

Under this article we will consider risk as a mental element of the civil responsibility of police officers, since the activities of police officers is precisely risky, and therefore in case of harm under justified risk, a person should be exempt from any kind of legal liability.

\section{Risk as a mental element of liability without fault}

In accordance with the provisions of Art. 1176, Part 1 of the Civil Code of Ukraine the injury caused by illegal actions of bodies of preliminary investigation, public prosecution and trial should be entirely compensate by the state regardless of fault of officials.

Traditionally, the concept of fault in domestic civil law coincides with the concept of fault in criminal law. Fault is the mental attitude of a person to his or her actions (unlawful behavior) and their result (breach of contract, harm, unjustified enrichment), the legal content of which is the desire or unwillingness of the occurrence of a wrongful result, the possibility or impossibility of predicting this result and its avoidance. Intent and negligence have traditionally been considered forms of guilt ${ }^{4}$.

As a general rule, fault is a necessary component of a civil offense, which requires the application of civil liability. According to of Art. 614, Part 1 of the Civil Code of Ukraine, the person who breached the obligation is

${ }^{2}$ Bondarchuk V.V. (2013). Ryzyk jak pravova kateghorija [Risk as a legal category]. Journal of Kyiv University of Law, no. 2. pp. 312-315.

${ }^{3}$ Cyviljnyj kodeks Ukrajiny: stanom na 30 veresnja 2018 r. [Civil Code of Ukraine: as of September 30, 2018]. Kharkiv: Law. (in Ukrainian).

${ }^{4}$ Dmitrieva O.V. (1997). Otvetstvennost bez viny v grazhdanskom prave [Liability without fault in civil law]. Voronezh: Ministry of Internal Affairs of the Russian Federation (in Russian). 
responsible in case of his (her) fault (intent or negligence), unless otherwise stipulated by the contract or law. Therefore, civil law presumes the fault of a person, that is, a person is guilty until he or she proves that he or she has taken all the measures necessary for the proper fulfillment of the obligation. This rule is confirmed by the provisions of Art. 614, Part 2 and Art. 1166, Part 2 of the Civil Code of Ukraine.

Liability without fault is an exception and applies only in cases expressly provided by law. Instead, I.S. Kanzafarova argues that in many cases civil law does not require the presence of all the elements of the crime. According to her opinion, the legal structure of the offense is alien to civil law, and the artificial spread of the criminal doctrine of the crime into the civil sphere has not only caused significant damage to the investigation of civil liability issues, but also led to the fact that the fundamental line between public and private law was violated ${ }^{5}$.

V.V. Parykusha, who disagrees with the views of those scientists, who do not consider innocent liability as civil one, is of the same opinion. Civil liability including liability without fault performs a compensatory function, unlike criminal liability, which performs punitive and corrective function and is reasonably linked to fault. It is important not to punish but to compensate the victim in full for civil liability, so in some cases fault has no legal value in bringing the offender to civil liability. The main thing is that there is harm and violated subjective rights of a person, which must be restored at any cost, even at the expense of the offender, though not innocent. Thus, liability without such an element of civil offense as fault is possible and it is quite normal for civil law, given the peculiarities of its functions ${ }^{6}$.

The justification of liability without fault in civil science was carried out in two directions. The first one was related to the search for objective reasons for the legislative assumption of no-fault liability, and the second one was the search for the subjective condition of such liability. Within the first direction of justification of liability without fault, the following theories were posed: justice; legal insurance; professional risk, which is now called "objective risk" theory; procedural benefits for the victim (procedural simplification); organizational and technical prevention and others ${ }^{7}$. However, as K. Adler correctly pointed out,

\footnotetext{
${ }^{5}$ Kanzafarova I.S. (2007). Teoretychni osnovy cyviljno-pravovoji vidpovidaljnosti v Ukrajini [Theoretical Foundations of Civil Liability in Ukraine] (Doctoral Thesis), Kiev: Institute of State and Law. V.M. Koretsky National Academy of Sciences of Ukraine.

${ }^{6}$ Parikusha V.V. (2010). Problemni aspekty cyviljno-pravovoji vidpovidaljnosti bez vyny [Problematic aspects of civil liability without fault]. Bulletin of the High Council of Justice, no. 2, 66-74.

${ }^{7}$ Dmitrieva O.V. (1997). Otvetstvennost bez viny v grazhdanskom prave [Liability without fault in civil law (in Russian).]. Voronezh: Ministry of Internal Affairs of the Russian Federation (in Russian).
} 
"Whatever liability (for the fault or no-fault) is enshrined in the law, it may turn out that the innocent will suffer in any particular case", that is, will be liable or compensate for accidentally caused damage.

The representatives of the second direction believe that the absence of fault in the attribution of no-fault liability does not mean that there is no subjective condition of civil liability in this situation. They argue that such condition is the risk of the offender.

What is risk? According to the definition given in the Great Interpretive Dictionary of Modern Ukrainian, "risk is the conscious possibility of danger, courageous, proactive action, action with the prospect of success, positive result; the possibility of loss or failure in any case" ${ }^{9}$. However, this definition is generalized and can be used in all spheres of society. To determine the legal nature of the risk, let's consider the views of the leading civilian scientists on this category.

According to $\mathrm{Yu}$.V. Baulin, risk is an objective state of danger of causing harm, in which it is not known whether this harm will occur or not ${ }^{10}$.

V.V. Baburin believes that risk is the conscious use of an opportunity to achieve the desired result by dangerous act or omission. Risk in its socio-legal significance is an important way of removing social and legal uncertainty, which causes tension in social relations ${ }^{11}$.

S.N. Bratus defines risk as conscious assumption of potential random events when operating a source of increased risk that entail negative consequences for others, and accepting these consequences by the owner of the source of increased risk ${ }^{12}$.

V.V. Yakovlev, for his part, argues that risk is possible only if a probable process is considered, and the decision-maker has the right to choose one or the other course of action or to refuse any of them ${ }^{13}$.

${ }^{8}$ Adler K. (1914). Otvetstvennost bez viny v grazhdanskom i ugolovnom prave [Liability without fault in civil and criminal law]. St-Petersburg: publishing house Law book store named after N.K. Martynov (in Russian).

${ }^{9}$ Busel V.T. (2005). Velykyj tlumachnyj slovnyk suchasnoji ukrajinsjkoji movy [The Great Explanatory Dictionary of Modern Ukrainian]. Kyiv; Irpin: Perun. (in Ukrainian).

${ }^{10}$ Baulin Y.V. (1989). K voprosu o professionalnom i khozyaystvennom riske $\mathrm{v}$ proekte Osnov ugolovnogo zakonodatelstva [To the issue of professional and economic risk in the Draft Fundamentals of the Criminal Law. State of Law, issue 1, pp. 226-229.

${ }^{11}$ Baburin V.V. (2009). Risk kak osnovanie differentsiatsii ugolovnoy otvetstvennosti [Risk as a basis for the differentiation of criminal responsibility] (Doctoral Thesis), Omsk: The Ministry of the Interior of the Russian Federation, Omsk Academy.

${ }^{12}$ Bratus S.N. (1973). Spornye voprosy teorii yuridicheskoy otvetstvennosti [Controversial issues of the theory of legal liability]. Soviet State and Law, no. 4, pp. 27-35.

${ }^{13}$ Mamaykin V.P., Shcherbakov V.N., Yakovlev V.V. (1996). Problema otsenki riska [The problem of risk assessment]. Life and Safety, no 4. pp. 103-108. 
V.A. Oygenzikht assesses risk from the standpoint of psychology and provides the following definition of the concept: "risk is the mental attitude of the actors to the result of their own actions or to the behavior of others, as well as the possible result of an objective case and accidentally impossible actions, expressed in the conscious assumption of negative, including irreversible, property consequences. The presumption of adverse effects from the possible result of such actions (events) means the assumption of these consequences or their imposition on the subjects who are "at risk" in this case ${ }^{14}$.

This is exactly how the police officers perceive the result of the performance of their duties. They carry out functions with a higher degree of social responsibility, which are associated with a significant level of danger or conditions of extreme need, and use objects that are sources of high risk (vehicles, weapons, service dogs, etc.). In such circumstances, the possibility of causing damage to life, health or property of a person cannot be completely excluded.

On the basis of the foregoing, we remain of the view of those scholars who believe that responsibility for risk in civil law has every reason to be responsibility in its own sense. Therefore, let's take a closer look at the views of those scientists who are adherents of the concept of subjective risk. Subjective risk theory has received the greatest development in the scientific works of V.A. Oygenzikht, S.N. Bratus and Yu.G. Basin.

The representatives of this theory believe that the absence of fault in the attribution of liability without fault does not mean that in this situation there is no mental element of civil liability. In their view, the mental element is the risk of the offender. Risk is, like fault and innocence, a mental attitude of the subject to his (her) behavior, which, however, is different from both fault and innocence. Thus, V.A. Oygenzikht explains that "risk differs from innocence by the fact that innocence always precludes any prediction and even any possibility of predicting the harmful consequences by the subject of his (her) behavior, and the conscious assumption inherent in the risk involves the prediction, at least not absolute, but in the form of an abstract opportunities. The fault implies the undoubted anticipation of the consequences or the possibility of such prediction, while assuming the same risk leaves a certain percentage of doubt, bearing in mind only a certain probability, but not an absolute necessity of the occurrence of the harmful consequences"15.

According to S.N. Bratus, the subjective basis for the emergence of a legal obligation to compensate for the harm and liability arising from the failure to

14 Oygenzikht V.A. (1971). Kategoriya riska v sovetskom grazhdanskom prave [Risk in Soviet Civil Law]. Jurisprudence, no. 5, pp. 64-70.

${ }^{15}$ Oygenzikht V.A. (1972). Problema riska v grazhdanskom prave [The problem of risk in civil law]. Dushanbe: Irfon. (in Russian). 
fulfill this obligation is the risk as a presumption of "probable", accidental conditions that cause adverse consequences for others ${ }^{16}$.

It is obvious that not all scientists agree with the representatives of this theory. Thus, the subjective concept of risk is criticized by T.I. Illarionova, who, in particular, points out that according to the rules of law risk is associated with chance, which, in the author's opinion, excludes mental attitude ${ }^{17}$. However, this statement is somewhat outdated, since not all the rules of the current Civil Code of Ukraine that contain the term "risk" use solely its objective understanding, linking the risk with chance, and secondly, thanks to the norms of the Civil Code of Ukraine connected with the concept of risk, the party to civil relations, in some cases, still has the choice to take (or not to take) all the necessary measures to reduce the negative consequences of the realization of such risk.

F.A. Vyacheslavov criticizes the subjective concept of risk as well, stating that such an understanding of risk goes against the traditions of both Roman and national civil law, as according to the classical interpretation of this category risk is considered an objective onset of certain consequences in the form of threat. The scientist considers the reason for the emergence of the subjective concept of risk in the fact that the understanding of this category was not based on the universal definition of risk as a possibility of certain harm, but on the usual day-to-day expression "to take risk"18.

It is difficult to agree with such a view of a scientist. The risk is possible only when the subject is engaged in some particular kind of activity (carries out scientific tests, saves the life of hostages, operates of a source of high risk). There is no risk in the situation, in which the subject does not take actions related to the occurrence of unfavorable consequences for him. The criterion of the individual's mental attitude to his (her) own actions (if the risk is directly related to the activity of the party to civil relations), or to certain circumstances independent of the will of the individual (e. g., actions of other persons) comes to the fore according to this concept. The threat of certain adverse effects is not considered a risk by itself, since on case of such a threat an individual must make his (her) own choice of behavior, within a certain alternative, and therefore makes a choice between several possible options for such behavior, evaluating them for expediency and effectiveness.

${ }^{16}$ Bratus S.N. (1986). Yuridicheskaya otvetstvennost i zakonnost [Legal responsibility and lawfulness]. Volume 1. Moskow: Science. (in Russian).

${ }^{17}$ Maidanyk R.A. (2007). Anomaliji v cyviljnomu pravi Ukrajiny [Anomalies in the Civil Law of Ukraine]. Kyiv: Justinian. (in Ukrainian).

${ }^{18}$ Vyacheslavov F.A. (2007). Raspredelenie riskov: ponyatie i znachenie v grazhdanskom prave [Risk allocation: the concept and meaning in civil law]. Bulletin of the Moscow University. M.V. Lomonosov, Series 11: Law, no. 4, pp. 74-91. 
We support the notion that liability without fault is based on the acceptance of risk and agree with the statement that the using the term "liability without fault" is incorrect, it is more correct to speak about liability for risk, since the real condition for imposing liability is the effect of an incident as a flip side of legal risk"19. This statement is well founded, but concerns only tort liability. Unlike tort liaility, contractual liability arises within preexisting legal relationships, which clearly define the debtor and creditor, their rights and obligations. The debtor, by entering into an agreement, compares or at least has to compare his capabilities with the content of the obligations assumed; he is aware of the nature of the obligations assumed and specifically provides for the possibility of liability in case of their breach. In this regard, the onset of contractual liability in the vast majority of cases is devoid of the factor of suddenness, and therefore risk ${ }^{20}$.

\section{Risk in the activities of police officers}

Therefore, on the basis of the stated above, we have succeeded in proving that police officers are liable exectly for risk when performing their duties. This is due to the fact that police officers are sometimes forced to make vital decisions in stressful situations, with neither time nor possibility to evaluate all the circumstances of the case for taking adequate measures to respond to it. In case of non-compliency of the measures taken to the circumstances of the case, police officers hold liable for the results. In this regard, most of them are constantly in a stress, which accordingly affects their mental state and the decisions they make.

The very work of police officers on the performance of duties imposed on them by law is a priori risky, since it may lead to a violation of the subjective rights and freedoms of a person. Risk involves the admission of adverse events and the willingness of the subject to take responsibility for them. This activity, as it was already noted, is the performance of the corresponding duties by police oficers.

Indeed, according to Art. 23 of the Law of Ukraine "On the National Police" (hereinafter - the Law) ${ }^{21}$ police officers in accordance with the tasks entrusted to them: 1) carry out preventive activities aimed at preventing the commission of offenses; 2) determine the causes and conditions contributing

${ }^{19}$ Ioffe O.S. (1975). Obyazatelnoe pravo [Law of Obligations]. Moskow: Legal Literature. (in Russian).

${ }^{20}$ Petrycyn N.T. (2012). Teoretyko-pravovyj analiz osoblyvostej cyviljnoji vidpovidaljnosti za ryzyk [Theoretical and legal analysis of the features of civil liability for risk]. Actual problems of State and Law. no. 64. pp. 325-330.

${ }^{21}$ Zakon Ukrajiny "Pro Nacionaljnu policiju" stanom na 05 ljutogho $2016 \mathrm{r}$. [Law of Ukraine on the National Police: current legislation as of February 05, 2016]. Kyiv: Alerta. (in Ukrainian). 
to the commission of criminal and administrative offenses, and take measures within their competence to eliminate them; 3 ) take measures to detect criminal and administrative offenses; terminate detected criminal and administrative offenses; 4) take measures aimed at eliminating threats to life and health of individuals and public safety resulting from the commission of a criminal, administrative offense; 5) promptly respond to allegations and reports on criminal, administrative offenses; 6) conduct pre-trial investigation of criminal offenses within the defined jurisdiction; 7) search for persons hiding from the bodies of pre-trial investigation, investigating judge, court, evading criminal punishment, missing persons, and other persons in cases prescribed by law; 8 ) conduct proceedings in cases of administrative offenses, make decisions on the use of administrative penalties and ensure their enforcement in cases specified by law; 9) deliver detained persons, suspected of committing a criminal offense and persons who committed an administrative offense in cases and in the order, prescribed by; 10) take measures to ensure public safety and order in the streets, squares, parks, squares, stadiums, railway stations, airports, sea and river ports, other public places, etc.

It is clear enough that when exercising such powers, police officers may encounter resistance from certain persons. To counter this, police officers have the right to use police measures that are acts or complex of acts of preventive or coercive nature that restrict certain human rights and freedoms and are used by police officers under the law to enforce the powers vested in the police (Article 29 of the Law).

Preventive police measures are: 1) verification of identity documents; 2) interviewing a person; 3) cursory inspection; 4) halt of the vehicle; 5) the requirement to leave some place and restrict access to the designated area; 6) restricting the movement of a person, vehicle or actual possession of the thing; 7) penetration into the dwelling or other possession of a person; 8 ) verification of compliance with the requirements of the permit system of law enforcement agencies; 9) the use of technical instruments and equipment with the functions of photo and video recording; 10) verification of compliance with the statutory restrictions on persons under administrative supervision and other categories of persons; 11) police care.

When exercising their authority police officers are empowered to apply the following coercive measures: 1) physical influence (force); 2) the use of special means; 3 ) the use of firearms. The rules and conditions for implication of police coercion measures are regulated by Art. Art. 42-46 of the Law.

The objectivity of risk when using police measures is obvious, since life and health of others, as well as their ability to exercise the rights and freedoms provided for in the Constitution and laws of Ukraine may depend on the actions of police officers. 
The subjectivity of risk is expressed in the right of police officers to make their own decisions on the implementation of the appropriate preventive measure. Indeed, Art. 43, Part 3 enshrines that the type and intensity of coercive measures are determined taking into account the specificity of the situation, the nature of the offense and the individual characteristics of the person who committed the offense.

Besides, in order for the risk to be justified, the applied police coercive measure must meet certain requirements, namely: 1) be lawful - a police officer is prohibited to apply any measures other than those determined by the laws of Ukraine; 2) be necessary - that is, for the performance of police powers it is impossible to apply another measure or its implementation will be ineffective, as well as such measure should caus the least harm to both the addressee of the measure and other persons; 3) be proportional - the damage caused to human rights or freedoms, protected by law by the law, or to the interests of society or the State, must not exceed the good for the protection of which it was applied, or the created threat of harm; 4) effective - the application of a coercive measure ensures exercise of the police powers.

The greatest risk, as we understand it, is related to the use of weapons. Indeed, the use of firearms almost always occurs in a stressful situation, in which it is very difficult to determine the nature and extent of the threat of an attack. In other words, it is quite problematic for a police officer to evaluate the possible consequences of a socially dangerous act, as well as the proportionality of the harm caused to the offender as a result of the use of a weapon, with the harm that may result from the unlawful act of the latter.

Therefore it is very important that the legal evaluation of the actions of the police officers be carried out impartially, without an accusatory bias, taking into account all the circumstances of the case. As I.V . Dymon correctly points out, "the use of firearms to kill is a complex psychological process for a police officer, since the activity of a police officer in each individual situation is formed on the motivational and value characteristics of the police officer's personality, his or her cultural and religious orientations, and, on individual features of social perception"22.

In the USA, for comparison, where police officers are forced to deal with dangerous, aggressive and armed crime in the same way as in Ukraine, in the majority of cases, such actions by US cops are considered legitimate, even if it has led to fatal consequences. For US police, the use of weapons against offenders is a common practice. For example, in the last 15 years, 179

22 Dymon I.V. (2014). Zastosuvannja voghnepaljnoji zbroji jak krajnjogho zakhodu administratyvnogho prypynennja [The use of firearms as the last resort of administrative termination]. Our law, no. 6, pp. 28-33. 
incidents involving the use of firearms have occurred in the jurisdiction of the New York Police Department. Only in three of these cases police officers were formally charged. And only one case case resulted in judicial sentence ${ }^{23}$.

Risk in the profession of police officer can be defined as the presence of the possibility of adverse conditions and the effects of adverse factors in professional situations, which can lead to inconclusive results with the mandatory presence of adverse effects for the police officer ${ }^{24}$.

P. Kabanov, when considering the problems of risk in the investigation of crimes commited by the representatives of law enforcement agencies, notes that the measures aimed at crime solving and investigation is characterized by decision-making in the absence of information.

The consequences of risk can be divided into two types: tactical and procedural.

Tactical consequences include the weakening of the evidential force of previously obtained information, the loss of tactical advantage, and in general lead to the complication of the investigative situation, combined with additional costs to neutralize the negative effects of risk ${ }^{25}$.

For example, in accordance with the provisions of Art. 223 of the Criminal Code of Ukraine no one has the right to penetrate into the dwelling or other possession of a person for any purpose, except with the voluntary consent of the person who owns it or on the basis of the order of the investigating judge solely in cases prescribed by law. An investigator, a prosecutor has the right to enter a dwelling or other possession of a person prior to order of an investigating judge only in urgent cases connected with saving human life and property or directly prosecuting persons suspected of committing a crime. In such a case, a prosecutor, an investigator in agreement with the prosecutor, is obliged to submit a request for a seach to an investigating judge after such actions have been taken. The investigating judge considers such a request in accordance with the requirements of Art. 234 of this Code, verifying, among other things, whether there were really grounds for entering into the dwelling or other possession of a person without the order of an investigating judge. If the prosecutor refuses to agree to the request of the investigator for the search or the investigating judge refuses to satisfy the request for search, the

23 Lukjanchuk S. (2016). Chomu policija SShA ne vaghajuchysj striljaje u pravoporushnykiv? [Why does the US police not hesitant to shoot offenders?] [Electronic resource]. Retrieved November 10, 2019 from http://cripo.com.ua/? sect_id $=1 \&$ aid $=208566$.

${ }^{24}$ Osintseva A.V. (2015). Viktimologicheskiy aspekt professionalnoy deyatelnosti sotrudnika politsii $\mathrm{v}$ kontekste professionalnykh riskov [Victimological aspect of professional activity of police officer in the context of professional risks]. Victimology, no. 4 (6), pp. 19-25.

${ }^{25}$ Kabanov P. (1989). Risk pri rassledovanii prestupleniy [Crime Investigation Risk]. Social legitimacy, no. 2. pp. 56-58. 
evidence established as a result of such search is inadmissible and the information obtained should be destroyed. In this situation there is a manifestation of risk. The purpose for conducting preliminary investigation is socially useful: it is to collect evidence of a socially dangerous act and the fault of a person in its commission. The mode of action in a situation, which is urgent and cannot be postponed may be chosen by the representative of the law enforcement agency on his (her) own. For example, a person involved in a crime has locked up in an apartment and an investigator believes that he (she) is trying to hide the traces of the crime. There are two options for an investigator: the first one is to contact an investigating judge for permission to search a dwelling; the second one - to conduct a search without obtaining such a permission. In doing so there is a risk in both options. In the first case, it is likely that during the time required to obtain a court permission, the suspect will conceal or destroy the traces of a crime, and the investigator will not be able to prove his (her) involvement in the crime. In the second case the court may find the actions of an investigator illegal and unsubstantiated, and in this case the evidence obtained during their conduct will lose probative value. Therefore, both the first course of action and the second one involve the risk of loss of evidence in the case.

To procedural (social and legal) consequences of the risk P. Kabanov includes restrictions on the rights of citizens, violation of their personal integrity, defamation of law enforcement agencies ${ }^{26}$.

Particularly problematic is the issue of the actions of law enforcement officers in extreme conditions. Extreme conditions mean circumstances of high degree of danger caused by phenomena of natural, biological and social nature and require from law enforcement agencies special organizational and legal measures and their resourcing. This set of factors that dramatically violate the normal conditions of life of the population, public safety and the rule of law significantly complicates law enforcement activities.

The sources that create extreme conditions can be divided into three groups: 1) phenomena associated with the actions of the natural forces of nature; 2) social phenomena related to human behavior; 3) phenomena caused by reasons of technical nature ${ }^{27}$.

Considering the second group of factors, it should be noted that the general condition is the unlawfulness of conduct, violation of public order,

${ }^{26}$ Kabanov P. (1989). Risk pri rassledovanii prestupleniy [Crime Investigation Risk]. Social legitimacy, no. 2. pp. 56-58.

27 Maydykov A.F. (1989). Predmet, zadachi i sistema kursa "Upravlenie organami vnutrennikh del $\mathrm{v}$ ekstremal'nykh usloviyakh" [Subject, tasks and system of the course "Management of law-enforcement agencies in extreme conditions"]. Moskow: Academy of the Ministry of Internal Affairs of the USSR. 
committing socially dangerous actions, etc. (for example, mass riots, hostagetaking, escape from a place of detention and custody). The cessation and elimination of these phenomena present the greatest difficulties for the law enforcement agencies, as they can cause death, serious harm in case of failure to take timely decisions and sufficient measures.

Extreme conditions change the usual methods of police officers activities. This is due to the situation of choice between the expediency and legality of the actions taken and the lack of the necessary legal regulation of the activities of police officers in such conditions.

\section{CONCLUSIONS}

Based on the stated above, we can conclude that risk as a subjective condition of civil liability of police officers is a multifaceted category that affects not only the norms of civil law, but also the norms of many other branches of law, especially criminal law. Risk is the necessary element of the activities of the National Police of Ukraine, as police officers are constantly forced to make decisions in precarious conditions and unusual situations when performing the duties on protection of human rights and freedoms, combating crime, maintaining public safety and order assigned to them by the law. In this regard, the majority of police officers are constantly under stress, which affects both their mental state and the decisions they make.

As A.P. Algin correctly points out, the risk causes the existence of a "situation of risk" in the activities of police officers, provided the following conditions are met: 1) the presence of uncertainty - it is difficult to predict the development of the situation; the probability of occurrence of negative consequences is quite high if the situation is not affected; 2) the need to choose an alternative (including the refusal to choose) - the behavior of police officer is governed by applicable law, but in the situation the line between what is allowed and necessary is rather blurred; 3 ) the opportunity to evaluate the possibility of implementing of selected alternatives - as a correlation of the possibility of occurrence of positive and negative results, depending on the decision ${ }^{28}$.

Therefore, in our opinion, risk as a mental element of civil liability of police officers is the policemen's awareness of the possibility of adverse consequences in the process of performance of the tasks to ensure the protection of human rights and freedoms, counteract crime, maintain public safety and order, assigned to them by law.

${ }^{28}$ Algin A.P. (1989). Risk i ego rol' v obshchestvennoy zhizni [Risk and its role in public life]. Moskow: Thought. (in Russian). 


\section{SUMMARY}

The article deals with the problem of risk as a mental element of civil liability of police officers. An accent is placed on the complexity of the problem of risk, its cross-sectoral nature. The article examines scientific approaches to the definition of the concept of "risk", studies the objective and subjective theories of risk. The author takes the view of those scholars who believe that responsibility for risk in civil law has every reasonable basis to be responsibility in its own sense, and argues that the performance of police duties is always linked to the risk, which they are conscious of. The article examines the objectivity and subjectivity of risk, as well as the criteria for justification of risk in police activity. Based on the study of the relevant legislation and police practice, specific examples of the calculated risk in the activities of police officers are provided. It is noted that the consequences of risk in police activities can be divided into two types: tactical and procedural; it is considered what these consequences are. Attention is drawn to the fact that the issue of police officers actions in extreme conditions is particularly problematic. The author's definition of risk as a subjective condition of civil liability of police is given. It is emphasized that the legal evaluation of the actions of the police officers be carried out impartially, without an accusatory bias, taking into account all the circumstances of the case.

\section{REFERENCES}

1. Adler K. (1914). Otvetstvennost bez viny $v$ grazhdanskom i ugolovnom prave [Liability without fault in civil and criminal law]. St-Petersburg: publishing house Law book store named after N.K. Martynov (in Russian).

2. Algin A.P. (1989). Risk i ego rol' v obshchestvennoy zhizni [Risk and its role in public life]. Moskow: Thought. (in Russian).Kryminaljnyj kodeks Ukrajiny. Stanom na 18 zhovtnja 2019 r. [Criminal Code of Ukraine: as of October 18, 2019]. Kyiv: Alerta. (in Ukrainian).

3. Baburin V.V. (2009). Risk kak osnovanie differentsiatsii ugolovnoy otvetstvennosti [Risk as a basis for the differentiation of criminal responsibility] (Doctoral Thesis), Omsk: The Ministry of the Interior of the Russian Federation, Omsk Academy.

4. Baulin Y.V. (1989). K voprosu o professionalnom i khozyaystvennom riske $\mathrm{v}$ proekte Osnov ugolovnogo zakonodatelstva [To the issue of professional and economic risk in the Draft Fundamentals of the Criminal Law. State of Law, issue 1, pp. 226-229.

5. Bondarchuk V.V. (2013). Ryzyk jak pravova kateghorija [Risk as a legal category]. Journal of Kyiv University of Law, no. 2. pp. 312-315. 
6. Bratus S.N. (1973). Spornye voprosy teorii yuridicheskoy otvetstvennosti [Controversial issues of the theory of legal liability]. Soviet State and Law, no. 4, pp. 27-35.

7. Bratus S.N. (1986). Yuridicheskaya otvetstvennost i zakonnost [Legal responsibility and lawfulness]. Volume 1. Moskow: Science. (in Russian).

8. Busel V.T. (2005). Velykyj tlumachnyj slovnyk suchasnoji ukrajinsjkoji movy [The Great Explanatory Dictionary of Modern Ukrainian]. Kyiv; Irpin: Perun. (in Ukrainian).

9. Cyviljnyj kodeks Ukrajiny: stanom na 30 veresnja 2018 r. [Civil Code of Ukraine: as of September 30, 2018]. Kharkiv: Law. (in Ukrainian).

10. Dmitrieva O.V. (1997). Otvetstvennost bez viny v grazhdanskom prave [Liability without fault in civil law]. Voronezh: Ministry of Internal Affairs of the Russian Federation (in Russian).

11. Dymon I.V. (2014). Zastosuvannja voghnepaljnoji zbroji jak krajnjogho zakhodu administratyvnogho prypynennja [The use of firearms as the last resort of administrative termination]. Our law, no. 6, pp. 28-33.

12. Ioffe O.S. (1975). Obyazatelnoe pravo [Law of Obligations]. Moskow: Legal Literature. (in Russian).

13. Kabanov P. (1989). Risk pri rassledovanii prestupleniy [Crime Investigation Risk]. Social legitimacy, no. 2. pp. 56-58.

14. Kanzafarova I.S. (2007). Teoretychni osnovy cyviljno-pravovoji vidpovidaljnosti v Ukrajini [Theoretical Foundations of Civil Liability in Ukraine] (Doctoral Thesis), Kiev: Institute of State and Law. V.M. Koretsky National Academy of Sciences of Ukraine.

15. Lukjanchuk S. (2016). Chomu policija SShA ne vaghajuchysj striljaje $\mathrm{u}$ pravoporushnykiv? [Why does the US police not hesitant to shoot offenders?] [Electronic resource]. Retrieved November 10, 2019 from http://cripo.com.ua/?sect_id $=1 \&$ aid $=208566$.

16. Maidanyk R.A. (2007). Anomaliji v cyviljnomu pravi Ukrajiny [Anomalies in the Civil Law of Ukraine]. Kyiv: Justinian. (in Ukrainian).

17. Mamaykin V.P., Shcherbakov V.N., Yakovlev V.V. (1996). Problema otsenki riska [The problem of risk assessment]. Life and Safety, no 4. pp. 103-108.

18. Maydykov A.F. (1989). Predmet, zadachi i sistema kursa "Upravlenie organami vnutrennikh del v ekstremal'nykh usloviyakh" [Subject, tasks and system of the course "Management of law-enforcement agencies in extreme conditions"]. Moskow: Academy of the Ministry of Internal Affairs of the USSR.

19. Osintseva A.V. (2015). Viktimologicheskiy aspekt professionalnoy deyatelnosti sotrudnika politsii $\mathrm{v}$ kontekste professionalnykh riskov 
[Victimological aspect of professional activity of police officer in the context of professional risks]. Victimology, no. 4 (6), pp. 19-25.

20. Oygenzikht V.A. (1971). Kategoriya riska v sovetskom grazhdanskom prave [Risk in Soviet Civil Law]. Jurisprudence, no. 5, pp. 64-70.

21. Oygenzikht V.A. (1972). Problema riska v grazhdanskom prave [The problem of risk in civil law]. Dushanbe: Irfon. (in Russian).

22. Parikusha V.V. (2010). Problemni aspekty cyviljno-pravovoji vidpovidaljnosti bez vyny [Problematic aspects of civil liability without fault]. Bulletin of the High Council of Justice, no. 2, 66-74.

23. Petrycyn N.T. (2012). Teoretyko-pravovyj analiz osoblyvostej cyviljnoji vidpovidaljnosti za ryzyk [Theoretical and legal analysis of the features of civil liability for risk]. Actual problems of State and Law. no. 64. pp. 325-330.

24. Vyacheslavov F.A. (2007). Raspredelenie riskov: ponyatie i znachenie $\mathrm{v}$ grazhdanskom prave [Risk allocation: the concept and meaning in civil law]. Bulletin of the Moscow University. M.V. Lomonosov, Series 11: Law, no. 4, pp. 74-91.

25.Zakon Ukrajiny "Pro Nacionaljnu policiju" stanom na 05 ljutogho 2016 r. [Law of Ukraine on the National Police: current legislation as of February 05, 2016]. Kyiv: Alerta. (in Ukrainian).

\section{Information about the author: \\ Olha Panchenko, \\ $\mathrm{PhD}$ in Law,}

District Officer of Mirgorod Police Department

34, Jakova Usyka str., Mirgorod, 37600, Ukraine

ORCID ID: orcid.org/0000-0003-4365-0495 